\title{
EVALUATION OF ADSORTIVE POWER OF CACTUS PEAR FORAGE WITHOUT PEEL FOR USE IN REMOVAL OF COMMON GASOLINE IN WATER BODIES
}

\author{
L. M. R. LIMA ${ }^{1, *}$, J. L. B. C. da SILVA², L. E. CAVALCANTE ${ }^{3}$, E. D. A. FEITOZA ${ }^{4}$, L. M. R. LIMA ${ }^{5}$
}

${ }^{1}$ Federal University of Campina Grande, Academic Unit of Biotechnology and Bioprocess Engineering, Sumé, Paraíba, Brazil

2,3.4 Biotechnology and Bioprocess Engineers, Sumé, Paraíba, Brazil

${ }^{5}$ State University of Paraíba, Department of Environmental and Sanitary Engineering, Campina Grande, Paraíba, Brazil

${ }^{*}$ Corresponding author. Federal University of Campina Grande, Academic Unit of Biotechnology and Bioprocess Engineering, Sumé, Paraíba, Brazil, Phone: +55 8333531886

e-mail addressl: mergia@ufcg.edu.br(L.M.R. Lima).

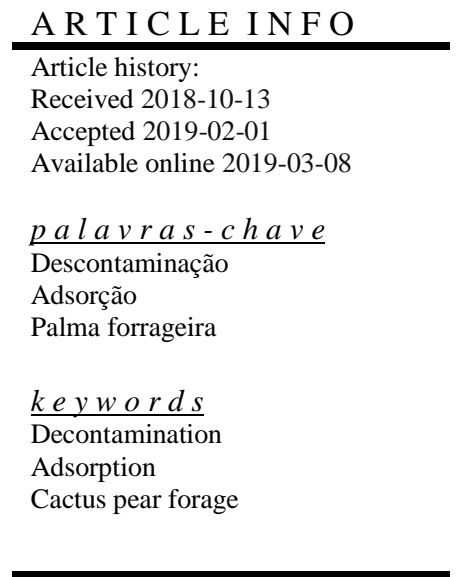

\begin{abstract}
A B S T R A C T
Alternative methods, as adsorption, with use of readily available and low cost materials have been used to remove contaminants in water bodies. Objective of this work was to study adsorptive power of cactus pear forage (Opuntia tuna Mill) biomass without bark as adsorbent for removal of gasoline in water bodies. Material underwent a natural drying process and then comminution to powder form. In adsorption kinetics study, were evaluated time between 5 and 60 minutes (with a 5-minute interval) and equilibrium concentrations of contaminants ranging from 5 to $50 \%$, with a 5\% variation rate. It was observed that process was rapid, with greater adsorption efficiency over time for 30 minutes. Langmuir model fitted well to experimental data, with a maximum adsorption capacity of $5.94 \mathrm{g.g}^{-1}$. Results confirm that cactus pear forage without peel appears as a promising biomass in gasoline adsorption process.
\end{abstract}

\section{R E S U M O/R E S U M E N}

Métodos alternativos, tais como a adsorção, com a utilização de materiais com fácil acesso e de baixo custo têm sido usados para retirada de contaminantes de corpos d'água. O objetivo desse trabalho foi estudar o poder adsortivo da biomassa palma forrageira (Opuntia tuna Mill) sem casca, como adsorvente para a remoção da gasolina em corpos d'água. O material passou por um processo de secagem natural e, em seguida, cominuição à forma de pó. No estudo de cinética de adsorção foram avaliados tempos de 5 a 60 minutos (com intervalo de 5 minutos) e no equilíbrio, concentrações de contaminantes variando de 5 a 50\%, com taxa de variação de $5 \%$. Observou-se que o processo foi rápido, com uma eficiência maior de adsorção no tempo 30 minutos. O modelo de Langmuir ajustou-se bem aos dados experimentais, com capacidade máxima de adsorção de $5,94 \mathrm{~g} \cdot \mathrm{g}^{-1}$. Os resultados confirmam que a palma forrageira sem casca surge como uma biomassa promissora no processo de adsorção da gasolina. 


\section{INTRODUCTION}

Due to accelerated economic development and intense industrial and commercial activity, environment has been constantly attacked, mainly by pollution of waters by oilderived hydrocarbons (PEREIRA; FREIRE, 2005; TIBURTIUS; ZAMORA, 2004).

Water scarcity is a worldwide problem, where concern is not only for discovery of new sources, but also for preservation and reuse of this limited resource on the planet.

Groundwater is a vital source of drinking water. There are several activities that have had impact on groundwater, such as inadequate disposal of liquid effluents and environmental accidents, which on many occasions involves spillage of petroleum products whose can generate a contamination load in these effluents (Fernandes, 1997).

Main sources of groundwater contamination are fuel stations, due to leaks occurring in storage tanks that, over time, present corrosion and, consequently, spilling of fuels occurring both soil and water contamination (Mioranza, 2015).

Adsorption process has been shown to be an efficient and economical method for treatment of effluents with organic pollutants, being necessary research of low cost materials to be used industrially. Adsorption success as a separation process depends on choice of adsorbent material and optimization of process variables (LIMA, 2010).

\subsection{Water body contamination by hydrocarbons}

Contamination of water bodies with hydrocarbons may pose a risk to aquatic ecosystems and human health. Effects vary depending on compound. Some hydrocarbons are carcinogenic and therefore may increase risk of cancer development (AGSOLVE, 2017). Hydrocarbons of benzene, toluene, ethylbenzene and xylenes, called BTEX, are components present in gasoline that have highest solubility in water and therefore are first contaminants to reach groundwater (ANALYTICAL ..., 2017).

A source of high potential for environmental pollution is storage of fuels in underground tanks, compromising soil and groundwater quality, which is a worrying aspect, since these waters are intensely exploited in Brazil (Silva et al., 2010).

Gasoline is a petroleum derivative formed by a complex mixture of more than 400 hydrocarbons from refining process (CULTIVAR ..., 2017). It presents a diversified composition due to its production process, petroleum characteristics and added additives to diminish effects to environment, increase its performance and reduce mechanical wear (Anjos, 2012)

Alternative methods combining removal of increasing contamination rates and low costs contaminants have been studied more frequently for treatment of effluents contaminated with hydrogen carbon compounds (Carvalho, 2014).

Adsorption process stands out as an alternative technique with great potential for treatment of effluents, mainly by using of natural products whose can be obtained from by-products of industry and agriculture. Many studies have proved efficiency of these adsorbents for treatment of water contaminated by oil, heavy metals and other toxic substances (Curbelo, 2002).

Main sources of groundwater contamination are fuel stations, due to leaks occurring in storage tanks that, over time, present corrosion and, consequently, spilling of fuels occurring both soil and water contamination (Mioranza, 2015).

\subsection{Adsorption}

Adsorption is a phenomenon in which molecules of a fluid concentrate on the surface of an adsorbent solid, with or without occurrence of chemical reactions (Luna, 2007). When solid adsorbent on which phenomenon occurs occurs with a given volume of a liquid containing adsorbable solute, called adsorbate, adsorption occurs until the equilibrium is reached, that is, when adsorbate is placed in contact with adsorbent, ions molecules tend to flow from aqueous medium to surface of adsorbent until the solute concentration in the liquid phase remains constant. At this stage it is said that system reached equilibrium and adsorption capacity of adsorbent is determined (Nascimento et al., 2014).

Adsorption is a separation and purification method that has enormous industrial applicability, mainly in chemical, petrochemical and biochemical sectors. Since discovery and commercialization of new adsorbent materials, this technique has been used to separate substances (Ruthven, 1984)

According to Oliveira (2016), adsorption, as shown in Figure 2, can be defined as a process in which molecules of a certain material, adsorbate, which are in the liquid or gaseous state, adhere to the surface of a solid material, called of adsorbent.

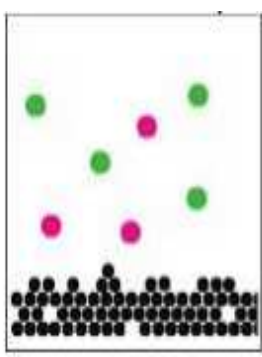

(a)

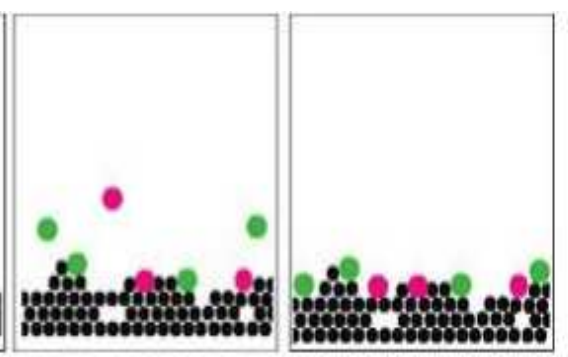

(b) (c)
Figure 1 - Schematic representation of adsorption process: (a) approximation of adsorbate to the adsorbent; (b) contact between molecules of contaminant and adsorbent (c) adsorption of adsorbent by adsorbate.

One of materials most used in adsorption process is activated carbon; however, due to its high cost and need for regeneration, other materials have been studied and used (Silva, 2005). Some low cost adsorbents are agricultural or industrial operation wastes that are readily available in large quantities, which makes them a low cost raw material (Coelho et al., 2014).

Adsorption kinetics: Adsorption kinetics describes rate of solute removal, being dependent on physical and chemical characteristics of adsorbate, adsorbent and experimental system. Rate at which adsorption will occur is influenced by agitation, temperature and $\mathrm{pH}$ of molecule and involves steps that can occur at different speeds. These steps are associated with diffusion of solute in particles of adsorbent. Steps are as follows: diffusion of adsorbate molecules from solution to external surface of adsorbents (boundary layer); adsorption of adsorbate molecules on outer surface of particle through molecular interactions; diffusion of adsorbate molecules from outer surface into the particle (effective diffusion) and adsorption within particle (LUZ, 2009). 
Adsorption kinetics are determined to establish ideal contact time between adsorbent and adsorbate, where influence of contact time between them aims to obtain an optimum agitation time for contact of adsorbate as an adsorbent (Zeferino, Freitas, 2013).

Adsorption equilibrium: For adsorption studies, evaluation of equilibrium is fundamental for understanding of processes. Adsorption equilibrium data are important in determining how much adsorbate can be trapped in adsorbent material (Luna, 2007).

In an adsorption process, equilibrium of system is reached when there are no liquid changes on adsorbate concentrations in solid phase and solute in the solution. Equilibrium reflects capacity and/or affinity of an adsorbent for a solute, under a given set of conditions under which system is subjected (Silva, 2005).

From information obtained from adsorption isotherm, it is possible to estimate total amount of adsorbent required for a given process (Luna, 2007).

In the case of northeastern semi-arid region in Brazil, there is a great variety of vegetation species that can be studied for adsorbent application, among which cactus pear forage, in its different genera, studied by Lima and Alves (2015) in removal of diesel oil in discard and Lima et al. (2016) for removal of lubricating oil.

\subsection{Northeast semi-arid of Brazil}

Semi-arid region of Northeast Brazil is characterized by climatic instability, which limits agricultural activities. It presents as a highlight climate, responsible for variation of other elements that compose landscapes. There are vegetation and relief formation process adapted to climate; soils are generally underdeveloped due to scarcity of rainfall (Araújo, 2011).

With regard to State of Paraíba, semi-arid area is of order of $48,785 \mathrm{~km} 2$ that corresponds to $86 \%$ of state area and it comprises 170 municipalities. In the 1990s, Paraíba's semi-arid already had a portion affected by processes of desertification, were already more than 2.8 million hectares, which corresponded to $49 \%$ of area of state. Its native vegetation has been greatly modified by man. Soils have undergone an intense desertification process due to replacement of natural vegetation by crop and pasture fields (Sá et al., 2013).

\subsection{Cactus pear forage}

Climatically defined arid and semi-arid regions represent approximately 48 million $\mathrm{km}^{2}$, distributed in $2 / 3$ of countries of the world. In these areas phenomenon of drought is normal and causes serious damage to agricultural sector. In Brazil, territorial area considered as semi-arid represents $11 \%$ of Brazilian territory and $60 \%$ of the Northeast region. This area is characterized by shallow soils of medium to high fertility, scarcity and irregularity of rains, having as main activity cattle raising (Oliveira et al., 2010).

Equipped with physiological mechanisms that make it one of plants most adapted to ecological conditions of arid and semi-arid zones of the world, cactus pear forage adapted with relative ease to semiarid of Brazilian Northeast; using as forage, began at the beginning of 20th century (Araújo, 2009).

Cactus pear forage, as shown in Figure 2, was introduced in Brazil at the end of 19th century and originated in Mexico. Its area of cultivation in Brazilian Northeast is of more than 400 thousand hectares, being most in Pernambuco and Alagoas (Santos et al., 2011). Originally grown only on American continent, it is currently distributed throughout the world, from Canada to Argentina. From Europe, where it was taken in 1520, this Mexican cactus spread from Mediterranean to Africa, Asia and Oceania (Oliveira et al., 2010).

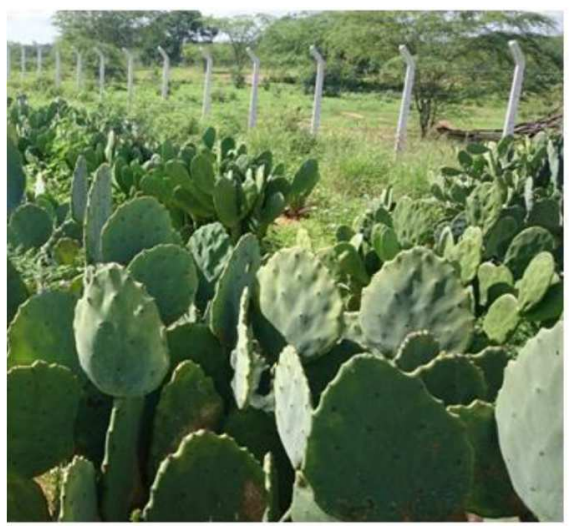

Figure 1 - Planting of cactus pear forage at the CDSA.

Cactus pear forage (Opuntia tuna Mill) stands out in the northeastern semi-arid region due to its enormous productive potential and multiple utilities (Leite, 2013). In addition, it becomes attractive for adsorption process, since in addition to contributing to reduction of environmental impacts caused by contamination of water bodies, it is a species of cultivar easily found in the region and resistant to periods of drought (Lima et al., 2016).

Thus, this work proposes an alternative for removal of gasoline from aqueous effluents by means of adsorptive processes, evaluating efficiency of cactus pear forage biomass as adsorbent, obtained through natural drying.

Main objective of this study was to evaluate adsorptive efficiency of cactus pear forage biomass (Opuntia tuna Mill) without peel, obtained from natural drying, when used for removal of gasoline present in water bodies. Adsorptive performance of biomass was evaluated by means of kinetic curves for characterization of adsorption dynamics between cactus pear forage adsorbent without peel and water/gasoline mixture and by isotherms obtained by equilibrium analysis.

\section{METHODOLOGY}

Contaminant used in experiments was gasoline, obtained from gas stations in the municipality of Sumé-PB. As adsorbent was used cactus pear forage (Opuntia tuna Mill) without peel in the particulate form.

Experiments were carried out at Federal University of Campina Grande-UFCG, Campus of Sumé-PB, in Laboratories of Organic Chemistry and Soils. Methodology was based on work of Lima et al. (2014). Cactus pear forage was collected from a planting of University itself; then whole peel of material was removed so that shelled cactus pear forage was exposed to the air for a period of three days. After this period, material was presented as shown in Figure 3. 


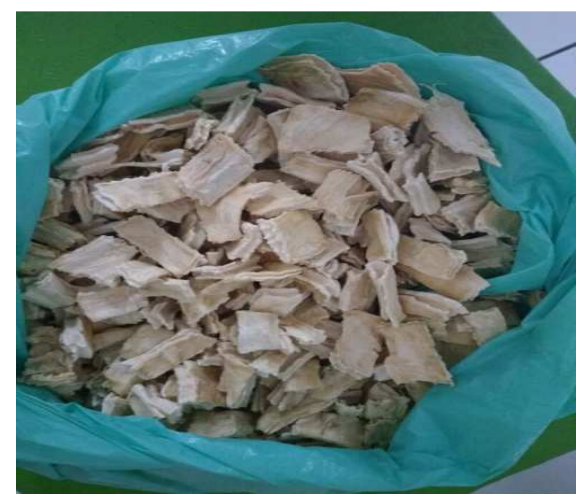

Figure 3 - Biomass after being subjected to open air drying.

After drying, cactus pear forage biomass was prepared in particulate form, in which raw material was submitted to comminution to powder form, using a knife mill to obtain granulometry in the range between 1 and $2 \mathrm{~mm}$.

\subsection{Adsorption kinetics}

For kinetics study, 12 Erlenmeyer flasks containing fixed amounts of water and gasoline $(40 \mathrm{~mL}$ of water and $12 \mathrm{~mL}$ of gasoline) were prepared and placed on a vibrating table, under shaking of $130 \mathrm{rpm}$, as shown in Figure 4.

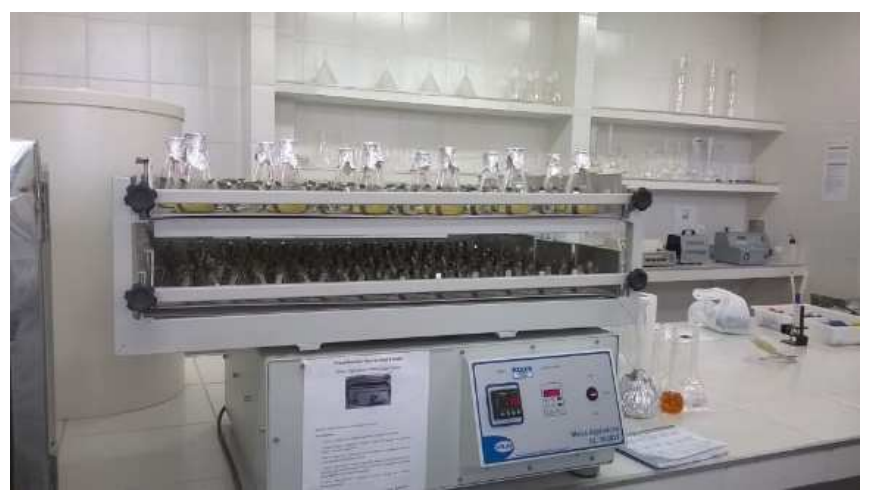

Figure 4 - Erlenmeyer flasks containing water, oil and biomass mixture under stirring on a vibratory table at 130 rpm.

Same amount of adsorbent was added to all vials (1.2 g) of adsorbent under study. Evaluated times ranged from 5 to 60 minutes, with an interval of 5 minutes for each Erlenmeyer. After stirring time, samples were filtered in a common sieve so that cactus pear forage (adsorbent) was retained in the sieve while liquid phase flowed. With aid of beakers of $100 \mathrm{~mL}$, volumetric measurement of samples was carried out at the end of contact time between adsorbate and adsorbent, in order to determine volume of gasoline adsorbed, as shown in Figure 5. At the end, mass of adsorbent was determined in an analytical balance.

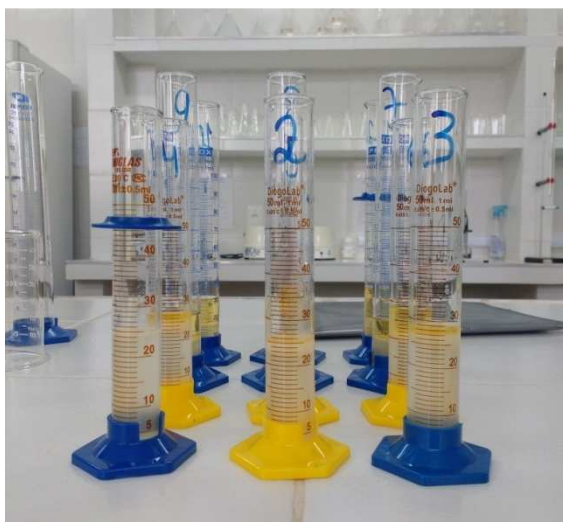

Figure 5 - Volumetric calibration of remaining gas volume in beakers.

\subsection{Equilibrium study}

For equilibirum balance study, 12 Erlenmeyer flasks, containing water and gasoline with a concentration range of 5 to $50 \%$, with a $5 \%$ variation for each flask were used, maintaining same amount of adsorbent for all flasks (1.2 g), under stirring at $130 \mathrm{rpm}$ for a period of 60 minutes. Then, sample was filtered with aid of a sieve and volumetric measurement was carried out in a beaker of $100 \mathrm{~mL}$ and, at the end of process, mass of adsorbent was determined.

Langmuir model: Langmuir isotherm model assumes that adsorption occurs in monolayers, where each adsorption site only interacts with a single molecule. Moreover, it assumes existence of a definite number of sites, all of same energy, and that molecules of adsorbate do not interact with each other. Equation 1 describes Langmuir model (Freire, 2016).

$q_{e}=\frac{q_{m} K_{a} C_{e}}{1+K_{a} C_{e}}$

Where $q_{e}$ is amount adsorbed in the equilibrium (mg. $\left.\mathrm{g}^{-1}\right), C_{e}$ is concentration of adsorbate in equilibrium (mg.L $\left.\mathrm{L}^{-1}\right), q_{m}$ is maximum adsorption capacity $\left(\mathrm{mg} \cdot \mathrm{g}^{-1}\right)$ and $K_{a}$ is Langmuir isotherm constant $\left({\mathrm{L} . \mathrm{mg}^{-1}}^{-1}\right.$

\section{RESULTS AND DISCUSSION}

\subsection{Adsorption kinetics}

Results obtained from kinetics experiments are shown in Table 1.

Table 1 - Results obtained from adsorption kinetics experiments.

\begin{tabular}{ll}
\hline Time (minutes) & $\mathbf{q}\left(\mathbf{g . g}^{-\mathbf{1}}\right)$ \\
\hline 5 & 3.66 \\
10 & 7.33 \\
15 & 7.66 \\
20 & 7.33 \\
25 & 8.66 \\
30 & 9.00 \\
35 & 8.66 \\
40 & 8.66 \\
45 & 8.66 \\
50 & 8.00 \\
55 & 8.33 \\
60 & 8.00 \\
\hline
\end{tabular}


From data obtained by adsorption kinetics experiments, a kinetic curve was done for amount of adsorbed gasoline in relation to the counting time and agitation, as shown in Figure 6.

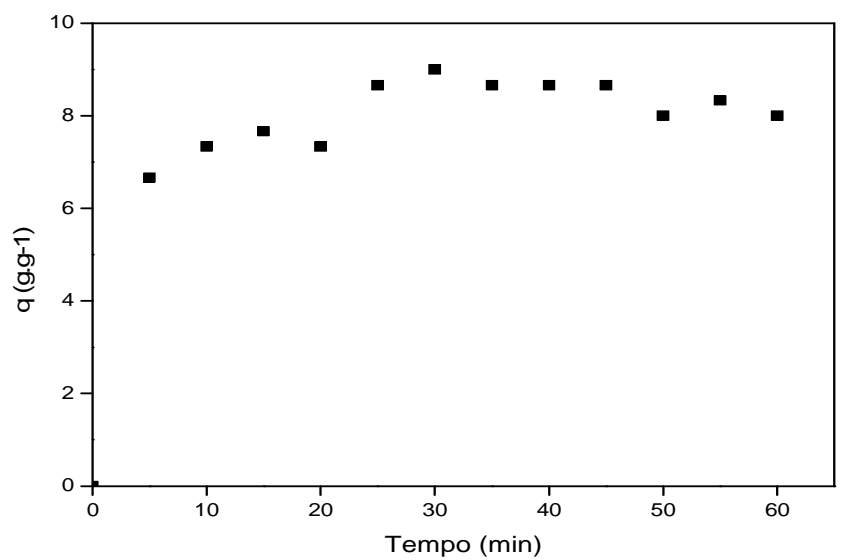

Figure 6 - Kinetic curve for adsorption of gasoline by cactus pear forage biomass.

It can be observed that rate of adsorption was rapid, with values close to first twenty minutes counted of gasoline with biomass. The best adsorption results were obtained after 20 minutes of contact. After this time an increase in adsorptive capacity of biomass was observed, being the best result observed in time of 30 minutes. It was also observed that, comparing with Martins (2016), use of cactus pear forage biomass (Opuntia tuna Mill) without peel has shown a better efficiency in adsorptive capacity in relation to cactus pear forage with peel.

\subsection{Adsorption equilibrium}

Results obtained from equilibrium experiments are shown in Table 2.

Table 2 - Results obtained from adsorption equilibrium experiments.

\begin{tabular}{ll}
\hline Concentração $(\%)$ & $\mathbf{q}\left(\mathbf{g} \cdot \mathbf{g}^{-1}\right)$ \\
\hline 0.00 & 0.00 \\
3.95 & 2.31 \\
6.11 & 3.37 \\
7.41 & 4.62 \\
11.98 & 5.32 \\
16.48 & 5.83 \\
17.72 & 5.43 \\
21.73 & 5.94 \\
31.00 & 5.54 \\
33.33 & 5.50 \\
\hline
\end{tabular}

To obtain equilibrium isotherms, a graph was constructed from obtained results, varying contaminant concentration from 5 to $50 \%$. Langmuir model was adjusted to results to evaluate adsorptive capacity of biomass, as shown in Figure 7.

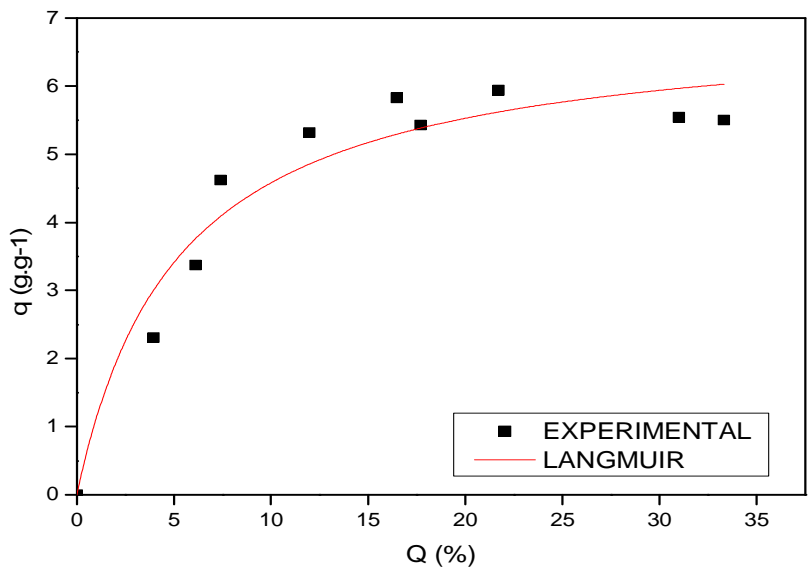

Figure 7 - Adsorption isotherm for cactus pear forage biomass dried naturally, adjusted to the Langmuir model.

Results indicate that maximum adsorption capacity (q) was 5.94 g.g ${ }^{-1}$. Comparing with Martins (2016), which obtained a maximum adsorption capacity of $5.445 \mathrm{~g}$, there was an increase in adsorption capacity with biomass without peel. It can be observed that Langmuir isotherm was well suited to results obtained.

\section{CONCLUSIONS}

From experiments carried out, it can be concluded that use of cactus pear forage without peel was considered satisfactory for use in decontamination of water bodies with presence of gasoline, using adsorption technique.

Adsorption kinetics were rapid, since in first five minutes of contact between mixture (water/gasoline) and adsorbent (cactus pear forage without peel), contaminant was removed by biomass.

Adsorption isotherm was well adjusted to Langmuir model, being favorable to adsorption. Adsorption equilibrium was reached, with significant values of removal of contaminant (5.94 g. $\left.\mathrm{g}^{-1}\right)$, comparing with existing literature.

Cactus pear forage without peel proved to be an efficient, economical and sustainable alternative for removal of gasoline present in water.

\section{R E F E R E N C E S}

AGSOLVE. Disponível em: <http:// www.agsolve.com.br>. Acessed on May 23 ${ }^{\text {th }}, 2017$.

ANALÍTICA AMBIENTAL. Disponível em: <http: // www.analiticaambiental.com.br $>$.Acessed on May $23^{\text {th }}$, 2017.

ANJOS, R. B. Avaliação de HPA e BTEX no solo e água subterrânea, em postos de revenda de combustíveis: estudo de caso na cidade de Natal- RN. 2012. $106 \mathrm{f}$. Dissertação (Mestrado em Ciência e Engenharia de Petróleo) - Universidade Federal do Rio Grande do Norte. Natal, RN, 2012.

ARAÚJO, A. M.; Interação entre adubação fosfatada e espaçamento no cultivo da palma forrageira (opuntia fícus-indica (l.) Mill) no estado da Paraíba. 2009. 68 f. Dissertação (Mestrado em Zootecnia) - Universidade Federal de Campina Grande, PB, 2009. 
ARAÚJO, S. M. S.; A região semiárida do nordeste do brasil: questões ambientais e possibilidades de uso sustentável dos recursos. Rios Eletrônica-Revista Científica da FASETE, Campina Grande, PB, ano 5, n. 5, dez. 2011. Universidade Federal de Campina Grande UFCG - PB, 2011

CARVALHO, E. S. Reuso do mesocarpo do coco na remoção de contaminantes derivados de petróleo presentes em corpos d'água, utilizando sistema de adsorção em leito diferencial. 2014. 54 f. Monografia (Graduação em Química Industrial) - Universidade Estadual da Paraíba. Campina Grande, PB, 2014.

COELHO, F. C., GONÇALVES JR, A. C., SOUSA, R. F. B., SCHWANTES, D., Miola, A. J., DOMINGUES, C. V. R. Uso de técnicas de adsorção utilizando resíduos agroindustriais na remoção de contaminantes em águas. Journal of Agronomic Sciences, Umuarama-PR, v.3, n. especial, p.291-317, 2014.

CULTIVAR. Disponível em: <http: //www.grupocultivar.com.br>. Acessed on May, $14^{\text {th }}$, 2017.

CURBELO, F. D. S. Estudo da remoção de óleo em águas produzidas na indústria de petróleo, por adsorção em coluna utilizando a vermiculita expandida e hidrofobizada. 2002. 102 f. Dissertação (Mestrado em Engenharia Química) - Universidade Federal do Rio Grande do Norte, Natal, RN, 2002.

FERNANDES, M. Influência do etanol na solubilidade de hidrocarbonetos monoaromáticos em aquíferos contaminados por gasolina. 1997. 115 f. Dissertação (Mestrado em Engenharia Sanitária e Ambiental) Universidade Federal de Santa Catarina, Florianópolis, SC, 1997.

FREIRE, T. M. Síntese e caracterização de nanoquitosanas magneticas por sonoquimica e sua aplicação na remoção de azo compostos. 2016. 87 f. Dissertação (Mestrado em Química) - Universidade Federal do Ceará. Fortaleza, CE, 2016.

LEITE, M. L. M. V. Palma Forrageira (Opuntia fícus indica e Nopaleacochenilifera). 2013. 31 f. Monografia (Graduação em Zootecnia) - Universidade Federal da Paraíba, Areia, PB, 2013.

LIMA, L. M. R. Estudo da ampliação de escala na adsorção de contaminantes orgânicos presentes em efluentes aquosos mediante leito fixo de biomassa. 2010. f. Tese (Doutorado em Engenharia de Processos), Universidade Federal de Campina grande. Campina Grande, PB, 2010.

LIMA L. M. R.; ALVES A. H. A. Estudo da eficiência adsortiva da biomassa palma forrageira (opuntia fícus) sem casca para uso na remoção de contaminantes orgânicos em águas de descarte de lava-jatos. In: XIII CONGRESSO DE INICIAÇÃO CIENTÍFICA DA UNIVERSIDADE FEDERAL DE CAMPINA GRANDE, 2016, Campina Grande, PB. Anais do XIII CONGRESSO DE INICIAÇÃO CIENTÍFICA DA UNIVERSIDADE FEDERAL DE CAMPINA GRANDE. Campina Grande: Universidade Federal de Campina Grande, UFCG. 2015 .
LIMA, L. M. R., COSTA, K. J. B., OLIVEIRA, E. D. C., OLIVEIRA, E. K. G., SANTOS, T. C., SILVA, V. L. M. M. Utilização do mandacaru (Cereus jamacaruna) como biomassa adsorvente de gasolina presente em corpos d'água, In: X Encontro Brasileiro sobre Adsorção, 2014, Guarujá, SP. Anais do X Encontro Brasileiro sobre Adsorção, 2014.

LIMA, L. M. R., TAVARES, D., OLIVEIRA, F. J. C., SILVA, J. L. B. C.; MARTINS, T. D. N.; LIMA, L. M. R. L. Avaliação do poder adsortivo da palma forrageira (Opuntia fícus) para remoção de contaminantes hidrogenocarbonados em águas de descarte. In: XXI Congresso Brasileiro de Engenharia Química, 1, 2016. Fortaleza-CE. Anais do XXI Congresso Brasileiro de Engenharia Química, 2016.

LUNA, F. M. T. Estudos de adsorção de poliaromáticos em materiais nanoporosos. 2007. 138 f. Dissertação (Mestrado em Engenharia Química) - Universidade Federal do Ceará, Fortaleza, CE, 2007.

LUZ, A. D. Aplicação de processos adsortivos na remoção de compostos BTX presentes em efluentes petroquímicos. 2009. 174 f. Dissertação (Mestrado em Engenharia Química) - Centro Tecnológico, Universidade Federal de Santa Catarina, Florianópolis, SC, 2009.

MARTINS, T. D. N. Estudo da capacidade adsortiva da biomassa palma forrageira (opuntia fícus) como adsorvente para remoção de contaminantes orgânicos em corpos d'água. 2016. 40 f. Monografia (Graduação em Engenharia de Biotecnologia e Bioprocessos) Universidade Federal de Campina Grande, Sumé, PB, 2016.

MIORANZA, D. T. Remoção de gasolina sintética de corpos hídricos utilizando carvão ativado como adsorvente. 2015. 84 f. Dissertação (Mestrado em Engenharia Química) - Universidade Federal de Santa Catarina, Florianópolis, SC, 2015.

NASCIMENTO, R. F.; LIMA, A. C. A; VIDAL, C. B.; MELO, D. Q.; RAULINO, G. S. C. Adsorção: Aspectos teóricos e aplicações ambientais. Fortaleza, CE: Imprensa Universitária, 2014.

OLIVEIRA, F. T.; SOUTO, J. S.; SILVA, R. P.; FILHO, F. C. A.; JÚNIOR, E. B. P. Palma forrageira: adaptações e importâncias para os ecossistemas áridos e semiáridos. Revista verde de agroecologia e desenvolvimento sustentável, Mossoró, RN, v. 5, n. 4, p. 27-37, 2010.

PEREIRA, W. S.; FREIRE, R. S. Ferro zero: uma nova abordagem para o tratamento de águas contaminadas com compostos orgânicos poluentes. Quim. Nova, São Paulo-SP, vol. 28, n. 1, p. 130-136, 2005.

RUTHVEN, D. M. Principles of adsorption and adsorption processes. New York: J. Wiley, 1984.

SÁ, I. B.; CUNHA, T. J. F.; TAURA, T. A.; DRUMONT, M. A.; Mapeamento da desertificação do semiárido paraibano com base na sua cobertura vegetal e classes de solos. In: XVI Simpósio Brasileiro de Sensoriamento Remoto, 2013, Foz do Iguaçu, PR. Anais do XVI Simpósio Brasileiro de Sensoriamento Remoto, 2013. p. 3112-3118. 
SANTOS, M. V. F.; CUNHA, M. V.; LIRA, M. A.; DUBEUX JR, C. B.; FREIRE, J. L.; PINTO, M. S. de C.; SANTOS, D. C.; SOUZA, T. C.; SILVA, M. C. Manejo da Palma Forrageira. In: $2^{\circ}$ Congresso Brasileiro de Palma e Outras Cactáceas, 2011, Garanhuns, PE. Anais do $2^{\circ}$ Congresso Brasileiro de Palma e Outras Cactáceas, 2011. P. 1-15.

SILVA, A. T. Influência da temperatura na adsorção do corante azul de metileno utilizando serragem de Pinus elliottiicomo um adsorvente alternativo: um modelo para o tratamento de efluentes têxteis. 2005. 45 f. Monografia (Graduação em Química) - Universidade Federal de Santa Catarina, Florianópolis, SC, 2005.

SILVA, M. L. R.; FAZZIO, A. L.; FREIRE, C. C.; FERREIRA, I. V. L. Postos de combustíveis e contaminação das águas subterrâneas: aspectos legais. In: IV Congresso de Engenharia, Ciência e Tecnologia, 2010, Maceió, AL. Anais do IV Congresso de Engenharia, Ciência e Tecnologia, 2010.

TIBURTIUS, E. R. L.; ZAMORA, P. P. Contaminação de águas por BTXs e processos utilizados na remediação de sítios contaminados. Quim. Nova, Curitiba-PR, vol. 27, n. 3, p. 441-446, 2004.

ZEFERINO, L. F.; FREITAS, P. A. M. Estudo cinético da adsorção do corante indigo blue (2,2-bis-2,3-diidro-3oxoindolilideno) em fibras de casca de coco verde (cocos nucifera l). Escola de Engenharia Mauá, 2013. 